\title{
Public-private partnerships as an important element of realization (implementation) of local government development strategies
}

\author{
Jovan Nešović1,* - Mirko Đapić ${ }^{2}$ \\ ${ }^{1}$ Public Energy Company "Toplana” Kraljevo \\ ${ }^{2}$ Faculty for Mechanical and Civil Engineering Kraljevo
}

\begin{abstract}
Public-private partnerships need to become a strong mechanism in the following period aiming infrastructure development at the local level. Local governments are faced with the lack of funds in the budget on the one hand, and with the demands of citizens, businesses and other beneficiaries for high quality services on the other hand. Solution to this problem should be sought in PPP at the local level. All factors in this process (local government, private enterprise, financiers) have an expressed motive (economic or political) for successful implementation of the project. Type of public-private partnerships depends on the type of infrastructure object, the total cost of investment and exploitation time. This paper presents three models of partnership depending on the manner the invested funds are returned, i.e. charge for object use, as follows: PPP projects that are charged to the end users, PPP projects that are charged to the local government and PPP projects with partial commercial use.
\end{abstract}

\section{Key words: strategic plan, project, public-private partnership, model}

\section{$0 . \quad$ INTRODUCTION}

Many local governments have adopted a development strategy for the medium to long term period, but their implementation is difficult to achieve due to lack of funds. During the formation of local budgets, care is primarily taken of providing funds for salaries, overheads and certain social allowances, and a smaller portion is intended for investments, primarily for infrastructure projects that ought to be the engine of development of a local government and improve the life quality for citizens living in the local government. Situation is similar at the state level, and this situation will definitely remain as such in the future period due to the economic crisis and low economic activity.

Therefore, respecting the legislation, local governments must enter into public-private partnerships (PPP) in the coming period in order to implement significant local infrastructure projects (these are mostly projects with significant financial value, so-called capital projects). In this way, by transferring part of the risk to private companies or investment funds in order to secure funding for the implementation of defined projects, the infrastructure problems are solved. On the other hand, these private companies want to gain certain profit, so this is the model that provides certain benefit to both parties (local government and private company).

Only public-private partnership is defined as a form of cooperation of a public and a private partner who work together on the implementation of investment projects and provision of public services [1]. Our legislation goes even further saying that public-private partnership is a long-term cooperation of a public and a private partner for the purpose of providing funding, construction, reconstruction, management or maintenance of infrastructure and other objects and provision of services of public significance and for the provision of services of public significance [2]. Implementation of PPP will be an important segment in the development of local governments in the coming period and a key factor for the achievement of defined strategic plans at the local level.

Projects that may be financed through PPP at the local level are: construction of local roads, utility infrastructure (water supply, sewage network), waste water treatment plants, water factories, schools, kindergartens, sports, health and social facilities, etc.

\section{MAIN PARTICIPANTS AND EXPECTATIONS FROM THE ESTABLISHMENT OF A PUBLIC- PRIVATE PARTNERSHIP}

Main participants in PPP projects for the construction of local infrastructure are: local government, private company, private financier and a PPP consultant.

Local government enacts a decision on the establishment, defines output results of the PPP, selects a private partner and provides partial payment of the private partner if needed.

Private company aims to implement the contracted PPP project efficiently. It may be formed by consortium with other qualifies legal entities in regard to the performance of works, maintenance of objects, financiers, consultants etc.

Private financier provides the capital or a loan to fund the project implementation. They also achieve returns from the charge for use of the public object by the beneficiaries or the local government. They require 
entering into PPP contracts that provide high quality of services and charging for project cost.

Consultant for PPP implementation may be hired either by the public or private partner during the preparation and implementation of the PPP project. Their engagement may be related to technical, financial and legal aspects of the partnership, and with their experience, they may point to best practices and potential problems and risks in the implementation of the PPP.

Public-private partnerships require active participation of all factors. Each participant in these projects has their requirements and objectives they wish to achieve. As the number of participants in the partnership rises, so the complexity of the overall process increases.

\section{a) Expectations of the private sector}

To enter into partnership with the public sector, the private sector has the requirements as follows:

- capital investment and application of knowledge based on experience in a certain field,

- getting reasonable profit and proportional increase of the profit potential,

- due to high exposure to risk, clear legal and regulatory structures,

- political support and stability,

- providing quality jobs for their company,

- getting references for possible future projects.

\section{b) Expectations of the public sector}

Public sector entering into partnership with the private sector expects the following:

- influence to project funding aiming to improve implementation thereof,

- acceleration of project implementation,

- improving level of service coverage,

- benefits resulting from the efficiency of project implementation (public support, savings in construction and maintenance costs, etc.)

- facilitating project performance with use of funds from external sources (Republic level of authorities, donors, etc.),

- satisfaction of beneficiaries,

- better economic environment for investors.

\section{v) Expectations of financial institutions}

Loans and guarantees are often sought from financial institutions and banks for the implementation of partnerships.

Before deciding to take part in the funding of local infrastructure projects, such institutions require:

- detailed financial analysis of the project,
- clear proof of security of approved funds,

- proof of technical equipment of the private partner and ability of the public sector to supervise the project implementation efficiently,

- clear procedures and legal regulations,

- political stability in the region.

\section{MODELS FOR PUBLIC-PRIVATE} PARTNERSHIPS IN THE IMPLEMENTATION OF LOCAL INFRASTRUCTURE PROJECTS

From the aspect of a model (way) of including the private partner into the development of local infrastructure, two ways are defined as follows: institutional and contracted PPP [1]. Institutional PPP includes formation of a joined business entity (company) for the implementation of the public project or provision of a public service. Parties' ownership share in such company is proportional to financial investment. Contracted PPP is the one where mutual relations, rights and obligations of the parties are regulated by a contract that shall be entered into on a definite time period. Today, when talking about PPP, we primarily think about contracted partnership, which is the one to be analyzed herein. Depending on the amount of investment, risks and property ownership, we distinguish three PPP models as follows:

- PPP projects where the end users pay fees to the private partner,

- PPP projects where the local government pays fees to the private partner and

- PPP projects with partial commercial participation.

What is common for all three models is that the private partner shall establish a company for special purposes (CSP) that is exclusively in charge of the implementation of the public contract, from providing funds to complete implementation of the project and its exploitation.

\subsection{Public-private partnership projects charged from the end users}

With this model, the PPP private partner undertakes the obligation to provide funds, design, construct, maintain and manage the contracted object, with the provision and charging for services to the end users. Total investment of the private partner is returned from the infrastructure usage fee or the price of services that the end users pay to the CSP. Amount, manner of collection and price of fee correction are defined in the contract on PPP project implementation. Constructed infrastructure is transferred to the local government at the end of the PPP contract. Should the fee (price) that the end users pay not be sufficient to cover the total project cost, the local government may support the project implementation by paying a capital subsidy or fee for the availability of the object, or by subsidizing service beneficiaries. 


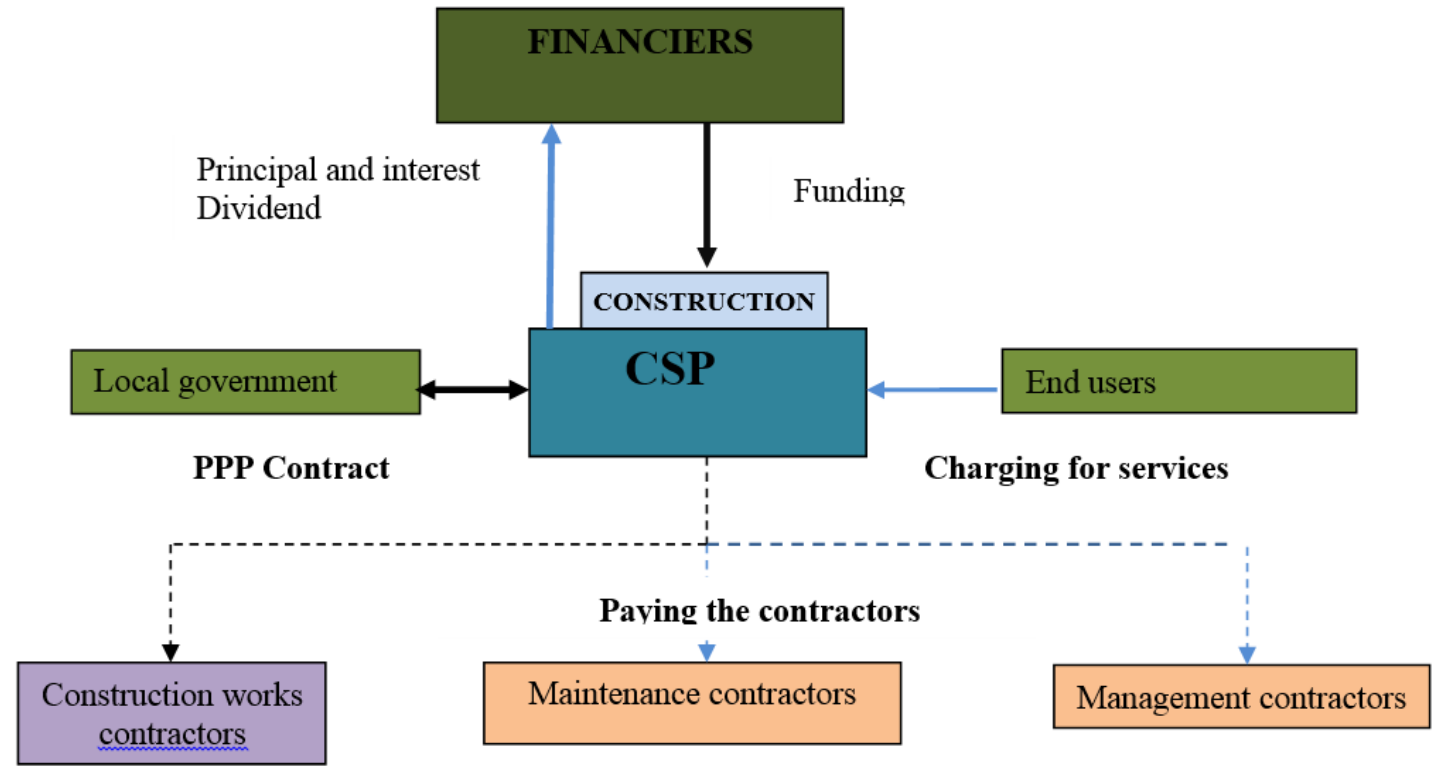

Fig. 1. Schematic diagram of PPP projects charged to the end users

\subsection{Public-private partnership projects charged from the local government}

Under this PPP model, the private partner undertakes the obligation to provide funding, design, construction and maintenance of the object. The local government undertakes the obligation to use the object and repay the total investment expenditures to the private partner by paying regular amounts for the availability pursuant to the contract. The newly constructed object shall be transferred to the ownership of the local government in accordance with the contract, and that's the end of the contract period. The private partner undertakes the risk of availability, or construction and maintenance for the object to be available in compliance with the criteria specified in the contract during the overall duration of the PPP project. The local government pays a fee for the availability during object use. What is good is that the fee is paid to the CSP in full amount only if the private partner effectively maintains the infrastructure or provides services. If the service fails to meet the contracted quality, the fee is reduced or even canceled until the contractual obligations are met.

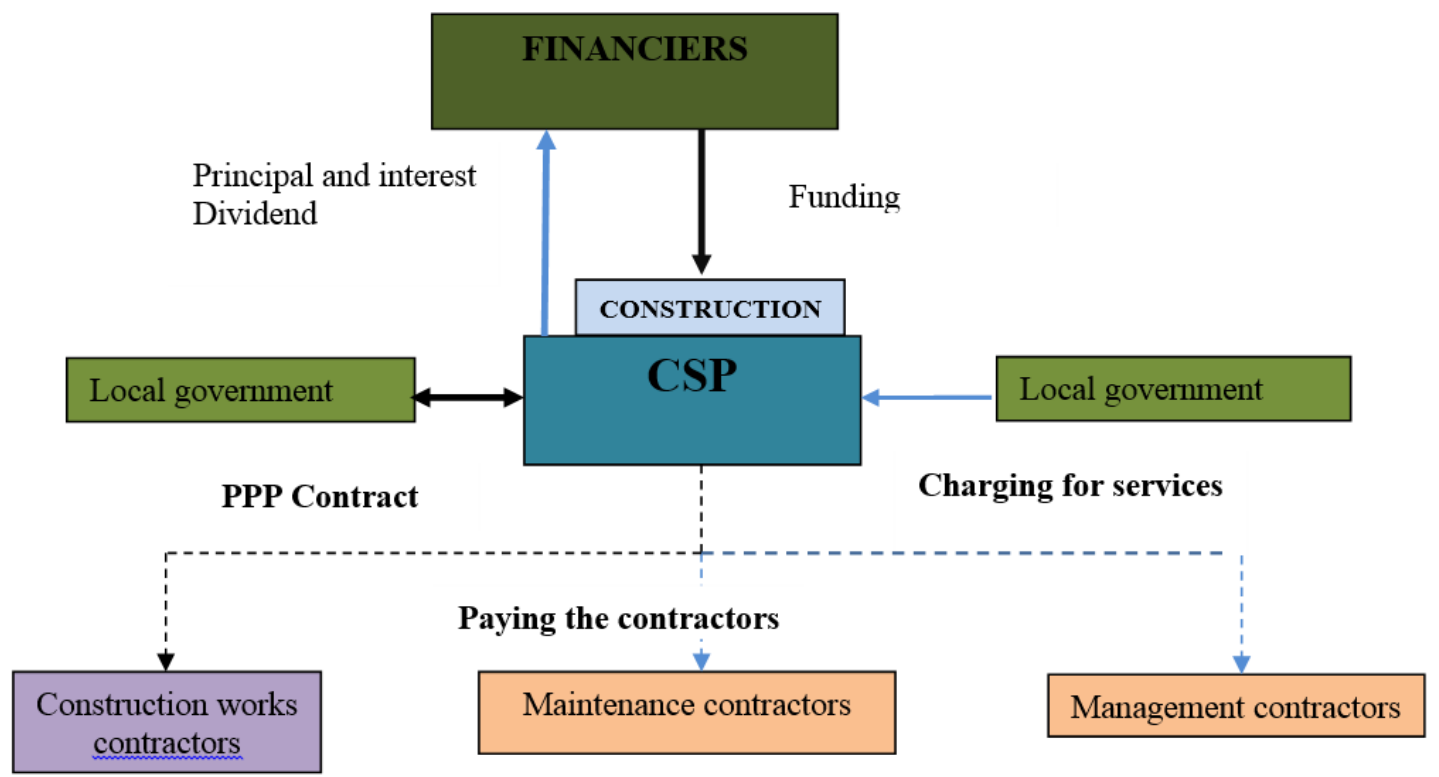

Fig. 2. Schematic diagram of PPP projects charged to the local government

2.3. Public-private partnership projects with partial commercial use
Under this PPP model, the private partner undertakes the obligation to provide funding, design, 
construction and maintenance of the object with the right of its partial commercial use. The local government is obligated to pay the fee for the availability of the public part of the object. The fee paid by the local government is significantly reduced for the amount of fee charged by the private partner to commercial users of the object.
Determining the amount and manner of charge for the object availability to the local government and commercial users is regulated by the PPP Project Contract as well as the manner of transfer of ownership of the newly built object to the local government.

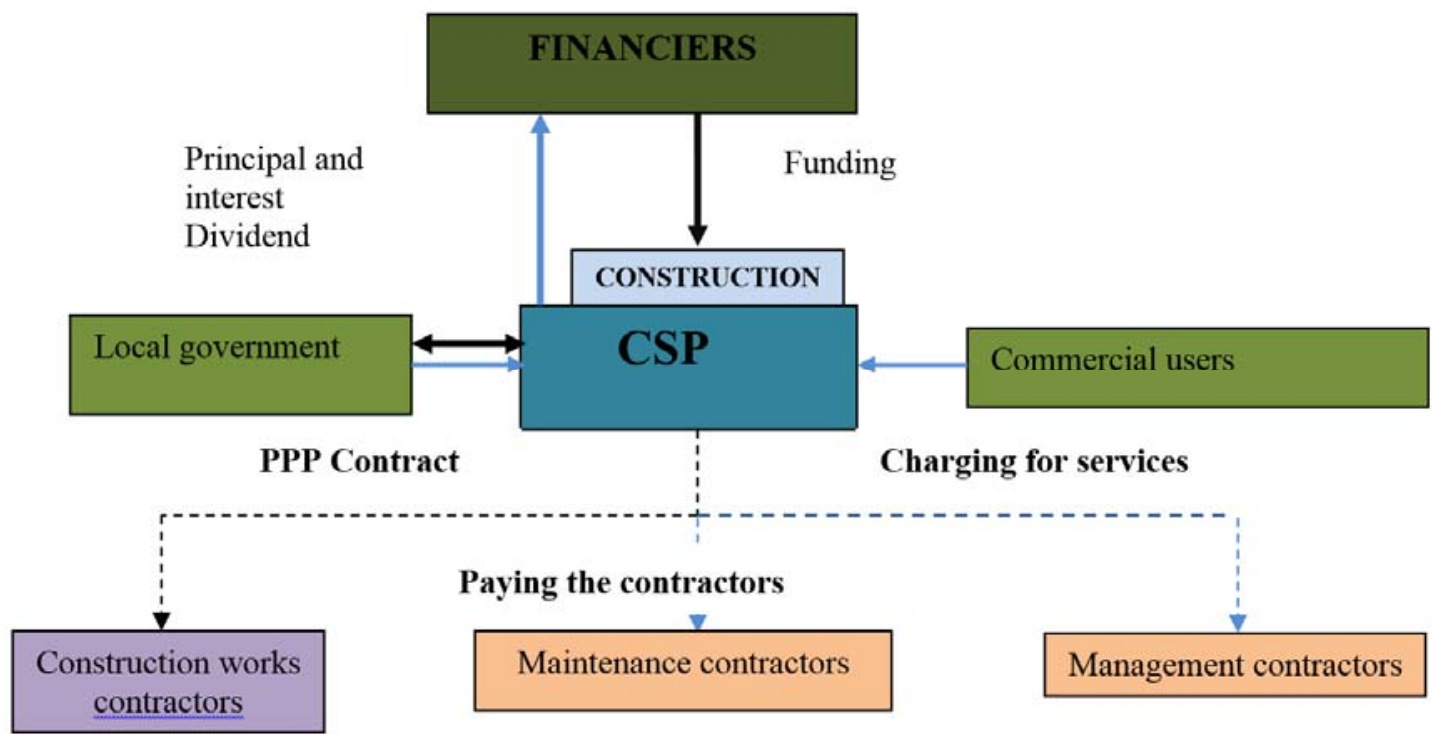

Fig. 3. Schematic diagram for PPP projects with partial commercial use

\section{EXAMPLES OF PUBLIC-PRIVATE PARTNERSHIP PROJECTS AT THE LOCAL LEVEL}

As for examples of public-private partnership that is charged to the end users there are several, and we will mention only a few: projects in the field of environmental protection (water supply, wastewater treatment, waste management), energy projects (cogeneration systems), public parking lots etc.

For public-private partnerships that are charged to the local government, we provide the following: schools, health facilities, welfare facilities, kindergartens and so on.

For public-private partnerships with partial commercial use, we provide the following examples: markets, public parking lots, sports facilities, cultural facilities and so on.

\section{CONCLUSION}

Implementation of development strategic plans in a local government directly depends on the financial resources that are available to that local government. Today in Serbia, local governments do not have enough money for development programs and projects, and that directly influences the level of economic development and quality of life. In the coming period, we should not expect a serious improvement in the state of finances at the local level and we should therefore look for some other models (ways) for the implementation of development projects.
A public-private partnership model is something that exists for a long time in the developed world and should be applied as soon as possible and as often as possible in our local governments. In addition to providing funds, PPP provides new knowledge and technologies in the construction of infrastructure objects, as well as their maintenance during exploitation. PPP model to be applied in a particular case depends on several factors (purpose of the facility, duration of the PPP, the total required funds for implementation, etc.), but it is important that the public sector provides a clear legal procedures and political stability. Good preparation and clear procedures provide a great opportunity for the success of the entire project.

\section{REFERENCES}

[1] mr Ljiljana Brdarević „Razvoj lokalne infrastrukture kroz javno-privatna partnerstva, priručnik za lokalne vlasti“" USAID program za Srbiju 2012.

[2] Jelena Bojović „Lokalni ekonomski razvoj priručnik za praktičare" THE URBAN INSTITUTE, Beograd 2010.

[3] Zakon o javno-privatnim partnerstvima i koncesijama, Službeni glasnik RS 88/2011.

[4] Zakon o lokalnoj samoupravi, Službeni glasnik RS $129 / 2007$.

[5] European Commission „, Guidelines for Successful Public-Private Partnership“, Brisel, 2003.

[6] European Commission , Green paper on PublicPrivate Partnership and Community Law on pablic contracts and concessions“, Brisel, 2004. 